\title{
Alkaloids as green and environmental benign corrosion inhibitors: An overview
}

\author{
C. Verma, ${ }^{1,2,3^{*}}$ E.E. Ebenso ${ }^{1,2}$ and M.A. Quraishi ${ }^{3}$
}

${ }^{I}$ Department of Chemistry, School of Chemical and Physical Sciences, Faculty of Natural and Agricultural Sciences, North-West University, Private BagX2046, Mmabatho 2735, South Africa

${ }^{2}$ Material Science Innovation \&Modelling (MaSIM) Research Focus Area, Faculty of Natural and Agricultural Sciences, North-West University, Private Bag X2046, Mmabatho 2735, South Africa

${ }^{3}$ Center of Research Excellence in Corrosion, Research Institute, King Fahd University of Petroleum \& Minerals, Dhahran 31261, Saudi Arabia

*E-mail: chandraverma.rs.apc@itbhu.ac.in, cbverma38@gmail.com

\begin{abstract}
Alkaloids are naturally occurring nitrogen containing organic bases that possess diverse and significant physiological effects on animals and humans. They are mostly derived from the plants. Because of their natural and biological origin, they (alkaloids) are considered as environmental benign alternatives to be used as corrosion inhibitors at the place of traditional and toxic synthetic corrosion inhibitors. Numerous alkaloids have been employed as effective corrosion inhibitors for metals and alloys in different electrolytic media. It has been established that alkaloid molecules are associated with extensive conjugation in the form of non-bonding and $\pi$-elections through which they can interact strongly and inhibit corrosion efficiently. Present review article features the collection of reports published on the topic alkaloids as corrosion inhibitors. In this review article, we also described the corrosion and its adverse effect, mechanism of corrosion and corrosion inhibition by organic corrosion inhibitors (including alkaloids) and factors affecting the inhibition property of corrosion inhibitors. Literature study suggests that most of the alkaloids are soluble in the polar electrolytic media and thereby behave as good corrosion inhibitors. Present review article describes the inhibition effect of several classes of alkaloids such as pyridine, purine and indole derivatives that have been used previously. Chemical structures alkaloids and their mode of adsorption and interactions with the metallic surface, nature of metal and electrolyte and related salient features have also been tabulated in the review.
\end{abstract}

Keywords: alkaloids, corrosion inhibitors, adsorption isotherms, green corrosion inhibitors, Hammett constants.

Received: March 27, 2019. Published: July 3, 2019

doi: $\underline{10.17675 / 2305-6894-2019-8-3-3}$ 


\section{Introduction}

\subsection{Corrosion and corrosion inhibition}

Metallic alloys are the most commonly employed constructional materials in industries and household applications because of their high mechanical power, high thermal and chemical stability and low cost [1-4]. Both ferrous and non-ferrous based alloys are being used as constructional materials in numerous industries including petroleum, marine, aerospace and petroleum industries [5-7]. However, these alloys are highly reactive and undergo corrosion particularly during some common industrial acidic cleaning processes such as acid descaling, oil well acidification and acid pickling. However, most of the metallic materials are very predisposed to corrosion by chemical and electrochemical reactions with surrounding components, particularly during the acidic cleaning processes that cause enormous safety and economic losses $[8,9]$. As per the recent report of NACE (National Association of Corrosion Engineers), estimated annual cost of corrosion is close to $\$ 100$ billion USD [10,11]. For the reason that corrosion causes massive trade and industry and safety losses, numerous preventive methods have been developed from time to time in order to prevent the corrosion and corrosive damages [12-15]. Out of all used methods, implementation of organic corrosion inhibitors is one of the most significant methods due to its several beneficial properties such as ease of synthesis, ease of application, costeffective and high inhibition performance [16-20]. High inhibition effectiveness of these organic inhibitors are linked with their highly electron rich adsorption centers. Generally, polar functional groups such as $-\mathrm{OH},-\mathrm{CN},-\mathrm{NH}_{2},-\mathrm{NO}_{2},-\mathrm{OCH}_{3},-\mathrm{CONH}_{2},-\mathrm{COOC}_{2} \mathrm{H}_{5}$, $-\mathrm{O}-,-\mathrm{S}-\mathrm{S}-,-\mathrm{SH},-\mathrm{NH}-\mathrm{CS}-\mathrm{NH}-,-\mathrm{CSNH}_{2},-\mathrm{PO}\left(-\mathrm{OC}_{2} \mathrm{H}_{5}\right)_{2},-\mathrm{NH}-\mathrm{SO}_{2}-$, etc. and extended conjugation in the form of homo and hetero-atomic double $(>\mathrm{C}=\mathrm{C}<,-\mathrm{S}=\mathrm{O}$, $-\mathrm{N}=\mathrm{O},>\mathrm{C}=\mathrm{O},>\mathrm{C}=\mathrm{N}-$ and $-\mathrm{N}=\mathrm{N}-)$ and triple bonds $(-\mathrm{C} \equiv \mathrm{N},-\mathrm{C} \equiv \mathrm{NC}-)$ act as adsorption centers $[2,21]$. In general, the polar functional groups of heteroatoms act as adsorption centers (interact with metallic surfaces) and multiple bonds enhance electron density at adsorption centers through conjugation. The interactions between organic inhibitors (or filming inhibitors) results into the adsorption and formation of surface film over the interfaces of metal and environments (or electrolytes) that isolates the metals from corrosive surrounding and protect from corrosion.

\subsection{Mechanism of Corrosion inhibition}

Corrosion in acidic medium causes the maximum economic and safety losses. The inhibitors can be classify into anodic, cathodic or mixed type depending upon their major retarding influence on anodic, cathodic or both reactions, respectively. Most of the organic reactions affect both anodic and cathodic reactions from their presence. In absence of the corrosion inhibitors, anodic dissolution and cathodic hydrogen evolution reactions of mild steel in aqueous medium can be presented as follows [22, 23]: 
(A). Anodic reactions

$$
\begin{gathered}
\mathrm{Fe}+\mathrm{H}_{2} \mathrm{O} \leftrightarrow \mathrm{FeOH}_{\mathrm{ads}}+\mathrm{H}^{+}+e^{-} \\
\mathrm{FeHO}_{\mathrm{ads}} \rightarrow \mathrm{FeOH}^{+}+e^{-} \\
\mathrm{FeHO}^{+}+\mathrm{H}^{+} \leftrightarrow \mathrm{Fe}^{2+}+\mathrm{H}_{2} \mathrm{O}
\end{gathered}
$$

(B). Cathodic reactions

$$
\begin{gathered}
\mathrm{Fe}+\mathrm{H}^{+} \rightarrow\left(\mathrm{FeH}^{+}\right)_{\mathrm{ads}} \\
(\mathrm{FeH})_{\mathrm{ads}}+e^{-} \rightarrow(\mathrm{FeH})_{\mathrm{ads}} \\
(\mathrm{FeH})_{\mathrm{ads}}+\mathrm{H}^{+}+e^{-} \rightarrow \mathrm{Fe}+\mathrm{H}_{2}
\end{gathered}
$$

However, in the presence of organic corrosion inhibitors in the acidic solution, mechanism of mild steel corrosion changes significantly. The anodic dissolution reactions in the presence of corrosion inhibitor (CINH) can be presented as follows [22, 23]:

$$
\begin{gathered}
\mathrm{Fe}+\mathrm{H}_{2} \mathrm{O} \leftrightarrow \mathrm{Fe}\left(\mathrm{H}_{2} \mathrm{O}\right)_{\mathrm{ads}} \\
\mathrm{Fe}\left(\mathrm{H}_{2} \mathrm{O}\right)_{\mathrm{ads}}+\mathrm{CINH} \leftrightarrow \mathrm{FeOH} \mathrm{ads}^{-}+\mathrm{H}^{+}+\mathrm{CINH} \\
\mathrm{Fe}\left(\mathrm{H}_{2} \mathrm{O}\right)_{\mathrm{ads}}+\mathrm{CINH} \rightarrow \mathrm{Fe}(\mathrm{CINH})_{\mathrm{ads}}+\mathrm{H}_{2} \mathrm{O} \\
\mathrm{FeOH}_{\mathrm{ads}}^{-} \rightarrow \mathrm{FeOH}_{\mathrm{ads}}+e^{-} \\
\mathrm{Fe}(\mathrm{CINH})_{\mathrm{ads}} \rightarrow \mathrm{Fe}(\mathrm{CINH})_{\mathrm{ads}}^{+}+e^{-} \\
\mathrm{Fe}(\mathrm{CINH})_{\mathrm{ads}}^{+}+\mathrm{FeOH}_{\mathrm{ads}} \leftrightarrow \mathrm{Fe}(\mathrm{CINH})_{\mathrm{ads}}+\mathrm{FeOH}^{+}
\end{gathered}
$$

It is imperative to remark that prompt oxidation of metallic materials in acidic medium results into the accumulation of positive charge, that favours the adsorption (physisorption) of negatively charged counter ions such as sulphate (from $\mathrm{H}_{2} \mathrm{SO}_{4}$ ), chloride (from $\mathrm{HCl}$ ), nitrate (from $\mathrm{HNO}_{3}$ ) and phosphate (from $\mathrm{H}_{3} \mathrm{PO}_{4}$ ) at the metallic surface [23-25].

Therefore, in exceedingly destructive acidic solution metallic faces turn out to be negatively charged because of the collection of counter ions. On the other hands, heteroatoms of organic inhibitors grow into positively charged owing to their protonation $[23,26]$. The negative charge metallic faces and positive charged organic inhibitors attracted each other through electrostatic force of attraction (physisorption). The cationic form of inhibitor molecules take the electrons originated from metallic surfaces and transform into their neutral forms with heteroatoms having their free lone pair of electrons. Subsequently, the organic inhibitors transfer (donation) their $\pi$ - and non-bonding electrons 
(coordination bonding) into the d-orbitals of superficial metallic atoms (chemisorption). However, metals are already electron rich species this type of electronic transfer causes interelectronic repulsion that favours transfer of electrons from the metallic d-orbitals to the anti-bonding molecular orbitals of the inhibitor molecules through the phenomenon of retro-donation (chemisorption) [23, 26]. The phenomenon of donation and retro-donation strengthen each other through synergism (similar to metal carbonyl interactions). On this basis, it can be concluded that metal surface-organic inhibitor interactions (or adsorption) are not either pure physical or not pure chemical but it an association of both kinds of interactions (physiochemisorption). Mechanism of anodic and cathodic corrosion inhibition by organic compounds is illustrated in Figure 1.

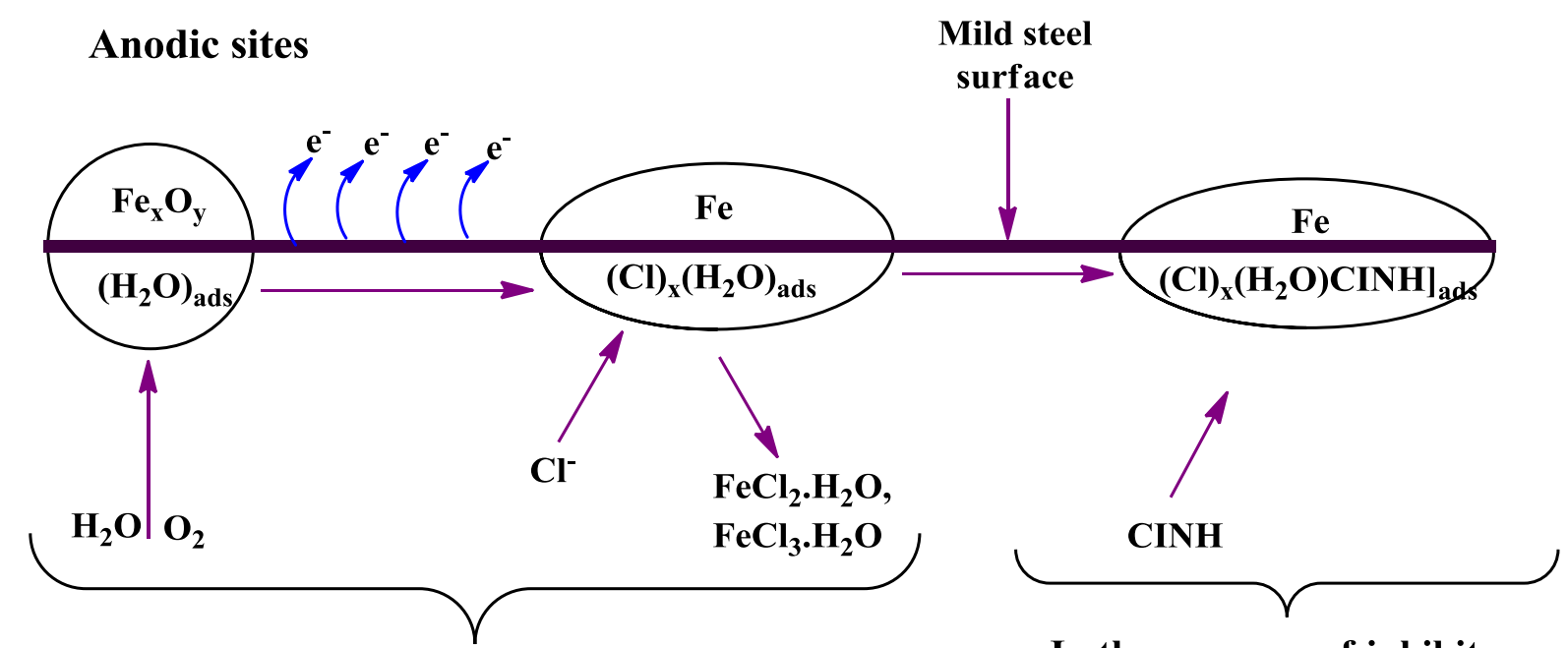

In the absence of inhibitors

In the presence of inhibitors

\section{Cathodic sites}

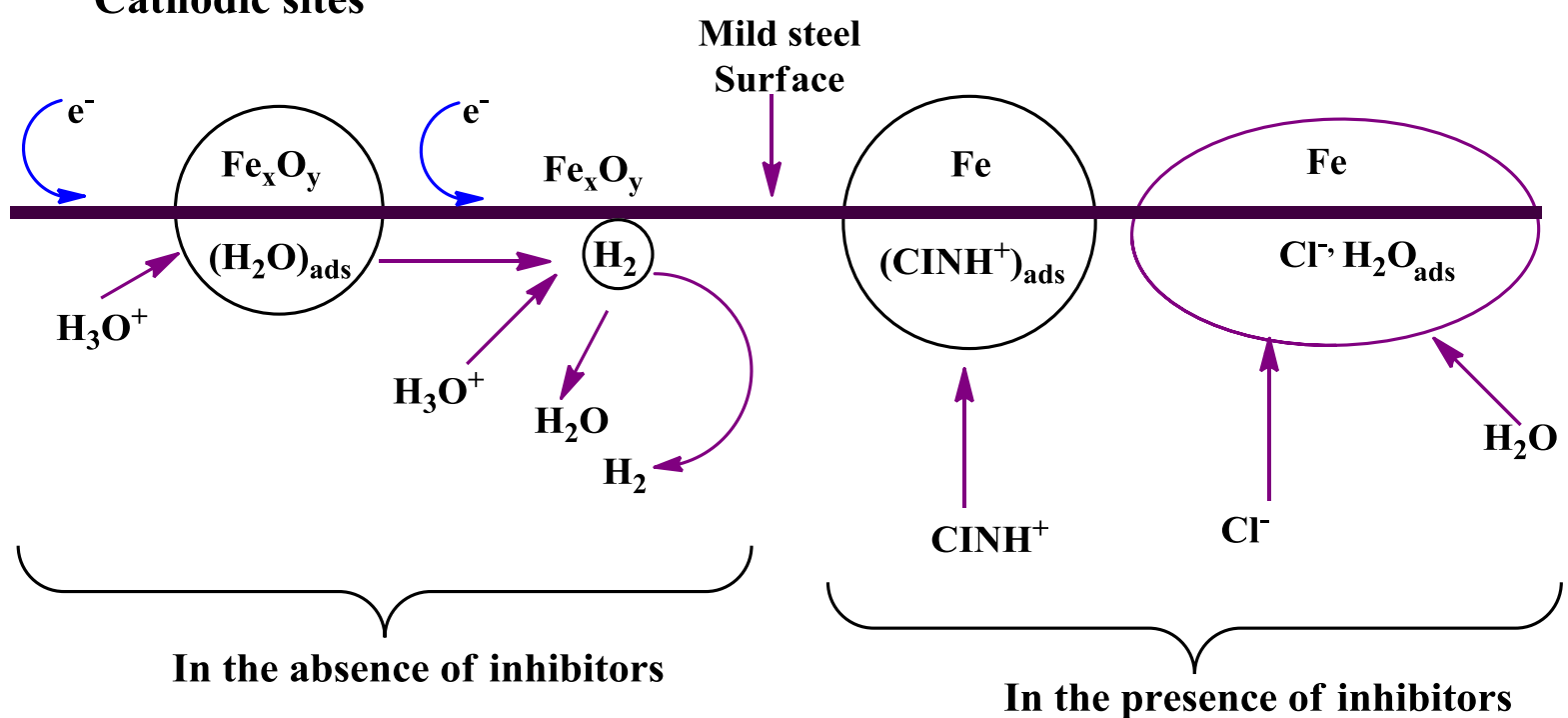

Figure 1. Corrosion inhibition mechanism of iron and its alloys by organic corrosion inhibitors in chloride based electrolytic media. 


\subsection{Effectiveness of corrosion inhibitors}

Except few noble metals, all pure metals are associated with high chemical reactivity because of their partially field d-orbitals therefore they naturally convert into their more stable forms by the chemical and electrochemical reactions (corrosion) with the surrounding components. There are several extensive and intensive factors that affect the corrosion rate of any metal or metallic material. Since corrosion is an interfacial interaction reaction of metal surface with the constituents of the surrounding environment, more reactive metals corrode more rapidly as compared to the less reactive metals. Presence of impurities helps in setting up the voltaic cells on the metallic surface and therefore enhances the probability and rate of corrosive degradation [27-29]. Presence of inorganic salts as impurities causes acceleration in the electrical conductivity of the electrolytes which in turn enhance the corrosion rate [30-32]. Besides the impurities, presence of oxygen plays an important role on the rate of corrosive degradation of metallic materials [32-34]. Obviously, presence of oxygen enhances the rate of corrosion and presence of different concentrations of oxygen results into the formation of differential aeration electrochemical cells that can accelerate the corrosion rate $[35,36]$. In general, high oxygen concentration regions behave as cathode whereas low oxygen concentration regions behave as anode in the differential aeration electrochemical cells. Similar to the oxygen, presence of water and moisture, presence of carbon dioxide, presence of electrolytes and rise in temperature enhances the corrosion rate $[37,38]$. There are several factors that affect the effectiveness of the organic inhibitors corrosion inhibitors. Increase in the aggressiveness of corrosive environments such as presence of impurity, increase in acidity and basicity, and increase in the flow rate of electrolyte and temperature cause the acceleration in the corrosion rate [39-41]. Generally, organic compounds undergo acid and / or base catalysed degradation (fragmentation) and rearrangement that adversely affect their inhibition performance. Similarly, acid/base catalysed fragmentation and molecular rearrangement at elevated temperature also reduces corrosion inhibition performance of the organic corrosion inhibitors [2,21]. Nevertheless, electronic structure of the organic compounds is one of the most effective factors that should be considered for the designing of the suitable corrosion inhibitors. Generally, presence of the electron releasing substituents those enhance the electron density either by inductive effect $(+\mathrm{I})$ or by resonance $(+\mathrm{R})$ such as $-\mathrm{OH},-\mathrm{NH}_{2},-\mathrm{NHMe},-\mathrm{NMe}_{2},-\mathrm{SH},-\mathrm{OMe}$ and $-\mathrm{SH}$, increase the corrosion inhibition performance of the organic inhibition. On the other hands, electron withdrawing substituents those withdraw electron by inductive effect $(-\mathrm{I})$ or resonance $(-\mathrm{R})$ such as $-\mathrm{CN},-\mathrm{NO}_{2},-\mathrm{OCH}_{3},-\mathrm{COOH},-\mathrm{COOC}_{2} \mathrm{H}_{5}$ etc. decrease the protection ability of the organic inhibitors. The effect of the substituent(s) on inhibition performance of the organic inhibitors can be best represented by their Hammett constant values. Simplified forms of the Hammett equation are presented below [42-44]: 


$$
\begin{gathered}
\log \frac{K_{\mathrm{R}}}{K_{\mathrm{H}}}=\rho \sigma \\
\log \frac{1-\eta \%_{\mathrm{R}}}{1-\eta \%_{\mathrm{H}}}=\rho \sigma \\
\log \frac{\eta \%_{\mathrm{R}}}{\eta \%_{\mathrm{H}}}=\log \frac{C_{r \mathrm{H}}}{C_{r \mathrm{R}}}=\rho \sigma-\log \frac{\theta_{\mathrm{R}}}{\theta_{\mathrm{H}}}
\end{gathered}
$$

In above equations, $\sigma$ is the Hammett constant and $\rho$ is the reaction parameter and its value mainly depends upon the nature of reaction. $K_{\mathrm{R}}$ and $K_{\mathrm{H}}, \eta \%_{\mathrm{R}}$ and $\eta \%_{\mathrm{H}}, C_{r \mathrm{R}}$ and $C_{r \mathrm{H}}, \theta_{\mathrm{R}}$ and $\theta_{\mathrm{H}}$ are the values of equilibrium constant, inhibition efficiency, corrosion rate and surface coverage by organic corrosion inhibitors with in the absence $(-\mathrm{H})$ and presence of substituent $(-\mathrm{R})$, respectively. The value of $\sigma$ gives information about the electron withdrawing and/or donating ability of the substituents present in inhibitor molecules. Generally, negative value of $\sigma$ is associated with electron donating ability of the substituent(s), whereas its positive value is consistent with electron accepting ability of the substituent(s). The detail description of the substituents effect can be found elsewhere. On this basis, it is concluded that compound containing electron releasing substituent or negative value of Hammett constant value acts better corrosion inhibitor as compared to the compound containing electron withdrawing substituent or positive value of Hammett constant value. However, several exceptions have also been reported in literature and in that cases effect of molecular size become more dominant as compared to the effect of substituents.

\subsection{Alkaloids as corrosion inhibitors}

Alkaloids are naturally occurring nitrogen containing organic bases that possess diverse and significant physiological effects on animals and humans [45, 46]. Alkaloids mostly present in plants and till today more than 3000 alkaloids have been identified from more than 4000 plants [47]. Although, biological functional of the alkaloids in plants is not properly established however it has been suggested that they are produce as the waste product of plant's metabolic activities $[48,49]$. In some studies, it has been reported as alkaloids help in the ripening of seed and protection of the plants from the destructive attack of insects $[50,51]$. Alkaloids can be classified into different categories depending upon their biosynthetic route, pharmacological activities, taxonomical origin and presence of major heterocyclic structure moiety. The classification of alkaloids based on the chemical structure of the nitrogen based heterocyclic compounds is one of the most frequent and commonly used methods. On this basis, alkaloids can be categorised into indoles, tropanes, pyridines, pyrrolidines, quinolines, isoquinolines, pyrrolizidines, steroids and terpenes etc. $[52,53]$. The basic skeleton of the alkaloids are given in Figure 2. Alkaloids are used as effective medicines in health care such as in heart failure, cancer, 
blood pressure, cough and migraine $[54,55]$. They are also used euphoric and addicting drugs, animals catching, research and scientific studies and insect killer (or replants). Literature survey reveals that there are several methods have been developed for the isolation of alkaloids from plants [56, 57]. It has been established that most of the organic corrosion inhibitors are toxic and non-environmental friendly in nature because of the multistep synthesis using toxic and expensive reagents and solvents [58-60]. Therefore, there is a vital demand of green and environmental friendly corrosion inhibitors derived from plants and natural origin. In this direction, utilization of plant extracts has gain substantial courtesy for the inhibition of metallic corrosion [61-63]. Generally, plants extracts contain several active phytochemicals those possess several adsorption centers in the form of polar functional groups of heteroatoms and extensive conjugation in the form of multiple bonds. These phytochemicals easily adsorb on the metallic surface using their adsorption centers and form protective barrier which isolates the metallic surface and protect from corrosion $[60,63]$.

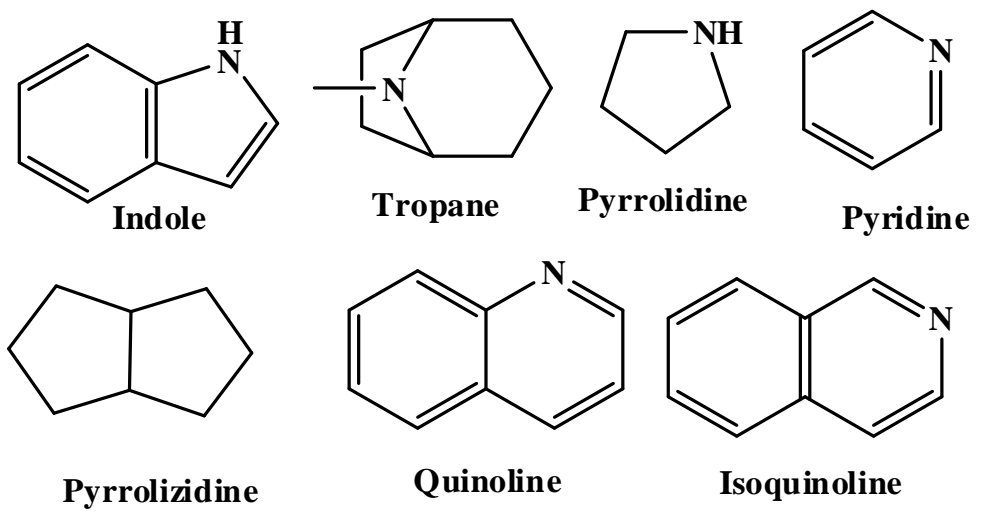

Figure 2. Basic heterocyclic structures present in different classes of alkaloids used as corrosion inhibitors for ferrous and non-ferrous alloys.

The corrosion inhibition effect of the plant extracts on different metals and alloys in numerous electrolytic environments have been described elsewhere [13, 60, 64]. Literature survey reveals that no systematic review is available on the topic "alkaloids as corrosion inhibitors". Presence review article feature the collects of alkaloids as corrosion inhibitors.

\section{Different family of alkaloids as corrosion inhibitors}

\subsection{Pyridine based alkaloids as corrosion inhibitors}

Pyridine derivatives represent as special class of nitrogenous heterocyclic compounds that have numerous industrial and biological applications [65, 66]. Pyridine derivatives have been widely employed for several pharmacological applications including their antioxidant, anti-tumor, anti-mutagenic, anti-atherosclerosis, neuromodulator, neuroprotector, anti-diabetic, hepatoprotector, anti-vasodilator and memory enhancer properties [67, 68]. Literature study shows that pyridine derivatives have also been employed as effective 
corrosion inhibitors for different metals and alloys in numerous electrolytic media [69-72]. The high protection ability of the pyridine derivatives are attributed to the presence of nonbonding electron pair of the pyridine nitrogen and six $\pi$-electrons of the aromatic ring that can act as adsorption centers during metal inhibitors interactions along with the other substitutes of the its derivatives. Numerous pyridine based alkaloids have also been investigated as effective corrosion inhibitors for metals and alloys. Espinoza-Vázquez et al. [73] studied the corrosion inhibition effect of nicotine on 1018 steel corrosion under turbulent situation using chemical an electrochemical methods. Inhibition effect of the nicotine was evaluated at its several concentrations ranging from $0-50 \mathrm{ppm}$ and it was observed that nicotine showed more than $90 \%$ inhibition efficiency. It was further demonstrated that under static condition, nicotine showed better inhibition performance as compared to the turbulent condition. Nicotine adsorbed on metallic surface through physisorption mechanism following the Langmuir adsorption isotherm. The study suggested that nicotine as long time corrosion inhibitor as it showed more than $87 \%$ inhibition efficiency after the immersion time of $72 \mathrm{~h}$. In another study [74], inhibition effect of nicotine and caffeine investigated for the corrosion of carbon steel in $3 \% \mathrm{NaCl}$ solution saturated with $\mathrm{CO}_{2}$ under static and turbulent conditions. Results showed that caffeine showed better inhibition performance $(>90 \%)$ as compared to the nicotine (>80\%). Both inhibitors adsorb spontaneously using physisorption mechanism and Langmuir adsorption isotherm model. Both studied inhibitors acted as long term corrosion inhibitors. Several experimental such as PDP, EIS, EDX and SEM methods were used to demonstrate the inhibition performance of nicotine and caffeine. Vinutha and coworkers [75] demonstrated the inhibition effect of benzyl nicotinate $(\mathrm{BN})$ on the corrosion of cold rolled steel in the acidic solution of $1 \mathrm{M} \mathrm{HCl}$ using gravimetric, electrochemical and density functional theory (DFT) methods. Results showed that BN acted as mixed type corrosion inhibitor. The BN strongly adsorb on the metallic surface obeying the Langmuir adsorption isotherm model. Inhibition effect of the $\mathrm{BN}$ enhances with its concentration and decreases on increasing the temperature. Results derived from the computational study carried out using DFT method were in good agreement to the results of the experimental studies. Nicotinic acid and its derivatives have also been employed for the inhibition of different metals in numerous electrolytic media [76-81]. It is important to mention that nicotine and its derivatives have widely presented in plant extracts particularly in the extracts of tobacco and kola trees. Therefore, their extracts have also been evaluated as effective corrosion inhibitors for metals and alloys [82-87]. Informations related to the pyridine based alkaloids as corrosion inhibitors are given in Table 1. 
Table 1. Informations related to some pyrimidine based alkaloids as corrosion inhibitors.

\begin{tabular}{|c|c|c|c|c|c|}
\hline S. No. & Chemical structure & $\begin{array}{l}\text { Nature of } \\
\text { metal and } \\
\text { medium }\end{array}$ & $\begin{array}{c}\text { Nature of } \\
\text { adsorption }\end{array}$ & Salient features & Ref. \\
\hline 1 & & $\begin{array}{c}\text { AISI } 1018 \\
\text { steel / } 1 \mathrm{M} \mathrm{HCl}\end{array}$ & $\begin{array}{l}\text { Langmuir } \\
\text { adsorption } \\
\text { isotherm }\end{array}$ & $\begin{array}{c}\text { Nicotine acted as good corrosion inhibitor for } \\
1018 \text { steel in acidic medium and it showed more } \\
\text { than } 90 \% \text { inhibition efficiency at } 10 \mathrm{ppm} \\
\text { concentration. }\end{array}$ & [73] \\
\hline 2 & & $\begin{array}{l}\text { AISI } 1018 \\
\text { low-carbon } \\
\text { steel / } 3 \% \mathrm{NaCl} \\
\text { saturated with } \\
\mathrm{CO}_{2}\end{array}$ & $\begin{array}{l}\text { Langmuir } \\
\text { adsorption } \\
\text { isotherm, } \\
\text { Mixed type } \\
\text { inhibitors }\end{array}$ & $\begin{array}{l}\text { Inhibition effect of the caffeine and nicotine was } \\
\text { measured in static as well as turbulent condition } \\
\text { having rotation of } 100,500 \text { and } 1000 \mathrm{rpm} \text {. } \\
\text { Results showed caffeine showed more than } 90 \% \\
\text { efficiency whereas nicotine showed more than } \\
80 \% \text { inhibition efficiency. }\end{array}$ & {$[74]$} \\
\hline 3 & $\mathbf{B N}$ & $\begin{array}{l}\text { Cold rolled } \\
\text { steel (CRS) / } \\
1 \mathrm{M} \mathrm{HCl}\end{array}$ & $\begin{array}{l}\text { Langmuir } \\
\text { adsorption } \\
\text { isotherm, } \\
\text { Mixed type } \\
\text { inhibitor }\end{array}$ & $\begin{array}{l}\text { Inhibition efficiency of BN increases with } \\
\text { concentration and decreases with temperature. } \\
\text { BN acquires the highest efficiency of } 96.6 \% \text { at } \\
500 \text { ppm concentration. DFT study provides } \\
\text { good insight about inhibition mechanism. }\end{array}$ & {$[75]$} \\
\hline 4 & nicotinic acid & $\begin{array}{l}\text { Mild steel / } \\
\qquad \mathrm{H}_{2} \mathrm{SO}_{4}\end{array}$ & $\begin{array}{l}\text { Langmuir } \\
\text { adsorption } \\
\text { isotherm, } \\
\text { Mixed type } \\
\text { inhibitor }\end{array}$ & $\begin{array}{l}\text { Nicotinic acid showed the inhibition efficiencies } \\
\text { of } 94-99 \% \text { at the concentration range of } 10^{-1} \text { to } \\
\qquad 10^{-7} \mathrm{molL}^{-1} \text {. }\end{array}$ & {$[76]$} \\
\hline
\end{tabular}




\section{S. No. \\ Chemical structure}

Nature of metal and medium

\section{Nature of} adsorption
Salient features

Ref.

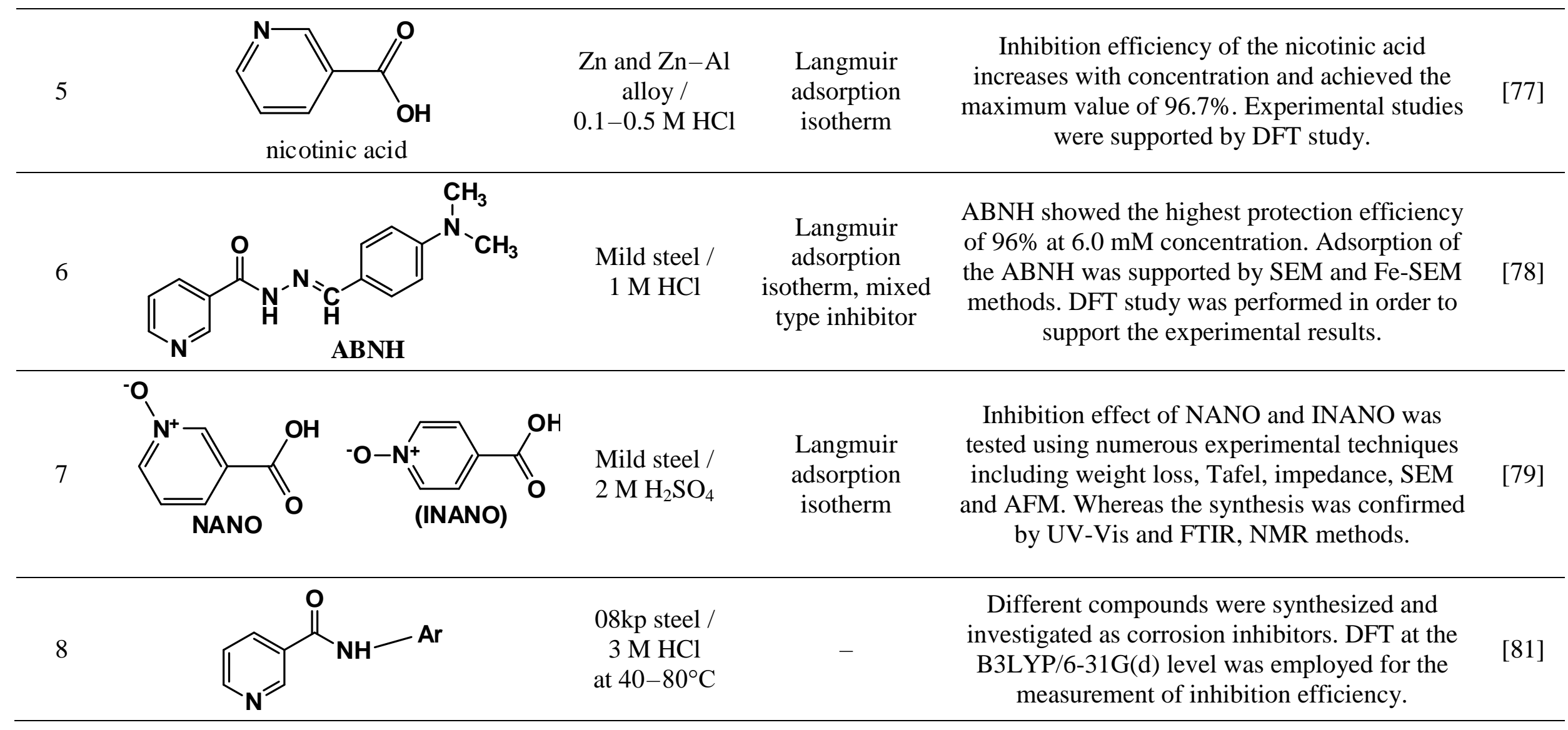




\subsection{Indole based alkaloids as corrosion inhibitors}

Indole is an aromatic heterocyclic compound in which five membered pyrrole rings is fused with benzene ring. Indole is widely distributed in nature and is produced by the several strain of bacteria. Indole and its derivatives represent several biological activities such as anti-fungal, anti-bacterial, anti-viral, anti-cancerous, anti-HIV, anti-oxidant, insecticidal, anti-tubular, plant growth regulator, plasmid stability, spore formation, biofilm formation, resistance to drugs and precursor for neurotransmitter serotonin formation etc. [88-90]. Because of the association of extensive $\pi$-electrons in the form of four double bond and two non-bonding electrons of pyrrole's nitrogen, indole and its derivatives are supported to show strong interactions with the metallic surface $[42,91]$. Examination of the literature suggested that, inhibition effect of indole and its derivatives have been reported in numerous reports [92-94]. Indole based alkaloids have also been tested as corrosion inhibitors. Kamal and Sethuraman [95] isolated Caulerpin (a bis-indole alkaloid) from Marine Alga Caulerpa racemosa and reported the inhibition effect of Caulerpin (a bis-indole alkaloid) on mild steel corrosion in $1 \mathrm{M} \mathrm{HCl}$ using weight loss, electrochemical and surface (AFM) investigation methods. The isolated Caulerpin was characterized using IR, UV-vis and NMR spectroscopic characterization. Electrochemical results showed that investigate alkaloid acted as interface and mixed type of corrosion inhibitor. Adsorption of the Caulerpin at the metal electrolyte interface obeyed the Temkin adsorption isotherm model. AFM study was adopted in order to corroborate the electrochemical and weight loss study. From AFM analysis it was observed that Caulerpin forms surface protective film at the metal-electrolyte interfaces. Raja et al. [96] studied the inhibition effect of alkaloids leaves and bark extracts of Ochrosia oppositifolia as well as one pure indole containing alkaloid namely isoreserpiline (ISR), on mild steel corrosion in $1 \mathrm{M} \mathrm{HCl}$. The inhibition effect of extracts and ISR was evaluated using SEM, EIS, PDP, FT-IR and DFT methods. Results showed that investigated inhibitors acted as mixed type corrosion inhibition and their adsorption obeyed the Langmuir adsorption isotherm model. FT-IR and DFT studies suggested that inhibitors strongly interacted as adsorbed on the metallic surface. Besides these reports, numerous plant extracts containing indole based alkaloids have been effectively tested as corrosion inhibitors for metals and alloys in various electrolytic environments [97-103].

\subsection{Purine based alkaloids as corrosion inhibitors}

Purine is well known water miscible nitrogenous heterocyclics compound in which imidazole ring is fused with pyrimidine ring. Purine derivatives are known as purines and they are mostly distributed in meat and meat products particularly in liver and kidney. They are essential building blocks of the DNA and RNA. Purines possess numerous biological applications such as antibiotic, antiviral, anticancer agents, antagonistic agents and cardiac blood flow regulators etc. $[104,105]$. Because of their association with the numerous non-bonding electrons of the nitrogen atoms and $\pi$-electrons of the both 
heterocyclic rings, purines can effectively interact with the metallic surface and thereby inhibit the corrosion. Several purine derivatives especially caffeine based alkaloids have been investigated as effective metallic corrosion inhibitors [106-108]. The inhibition effect of caffeine on copper corrosion in $0.1 \mathrm{M} \mathrm{H}_{2} \mathrm{SO}_{4}$ was evaluated by Souza et al. using numerous experimental methods [109]. Results showed that caffeine spontaneously adsorb over the metallic surface obeying the Temkin adsorption isotherm model. PDP results suggested that caffeine acted as cathodic type corrosion inhibitors. Contact angle study suggested the formation of hydrophobic inhibitive film by caffeine. The inhibition effect of the caffeine was tested at it 1-10 mmol concentration. SEM, EDS and flurescence studies suggested the adsorption of the caffeine over the metallic surface. The inhibition effect of caffeine based compounds on copper [110-113], nickel [114], mild and carbon steel [115-118] and aluminum [119] corrosion in other electrolyte systems have also been reported in other studies. Besides the above reports, Mahmood reported the corrosion inhibition effect of theobromine, a purine based alkaloid on the corrosion on mild steel in acidic solution of $\mathrm{HCl}$ [119]. He observed that theobromine acted as efficient corrosion inhibitor and its adsorption on the metallic surface obeyed the Langmuir adsorption isotherm model. The inhibition effect of another purine based alkaloid namely aminophylline of corrosion degradation of the mild steel in $1 \mathrm{M} \mathrm{HCl}$ was reported [120].

\section{Conclusions and outlooks}

On the basic of ongoing discussion and reports published in the literature it can be concluded that alkaloids are an important class of naturally occurring nitrogenous based heterocyclic compounds that play a significant role for several biological reactions. Because of their natural and plant origin, alkaloids are considered to be green and environmental benign alternative to substitute the toxic and expensive organic corrosion inhibitors. Obviously, alkaloid molecules are associated with high conjugation in form of non-bonding and $\pi$-electrons through which they can adsorb effectively and thereby inhibit the corrosion. Most of the alkaloids are soluble in the polar electrolytic media and thereby behave as good corrosion inhibitors. Several classes of alkaloids such as pyridine, purine and indole derivatives have been used extensively. However, owing to their natural and plant origin, environmental friendly behaviour, cost-effective nature and wide distribution, the application of the alkaloids as corrosion inhibitors should be explored. Further, literature study suggested that mostly pyridine, purine and indole derivatives are evaluated as corrosion inhibitors whereas literature on other alkaloids is relatively scare. Therefore, the application of other alkaloids on inhibition of metallic corrosion in different electrolytic media should be explored further.

\section{Acknowledgements}

CV, thankfully acknowledges the North-West University (Mafikeng Campus) South Africa for providing financial support for the study under postdoctoral study. 


\section{References}

1. M. Finšgar and J. Jackson, Corros. Sci., 2014, 86, 17-41.

2. C. Verma, L.O. Olasunkanmi, T.W. Quadri, E.-S.M. Sherif and E.E. Ebenso, J. Phys. Chem. C, 2018, 122, 11870-11882.

3. Y.P.A. Jeeva, G.S. Mali, R. Dinakaran, K. Mohanam and S. Karthikeyan, Int. J. Corros. Scale Inhib., 2019, 1, 1-12.

4. S. Bouazama, J. Costat, J. M. Desjobertb, A. Ben Ali, A. Guenbour and M. Tabyaoui, Int. J. Corros. Scale Inhib., 2019, 1, 25-41.

5. F. Bentiss, M. Traisnel and M. Lagrenee, Corros. Sci., 2000, 42, 127-146.

6. J. Aljourani, K. Raeissi and M. Golozar, Corros. Sci., 2009, 51, 1836-1843.

7. Y. Li, P. Zhao, Q. Liang and B. Hou, Appl. Surf. Sci., 2005, 252, 1245-1253.

8. G. Manivasagam, D. Dhinasekaran and A. Rajamanickam, Recent Pat. Corros. Sci., 2010, 2, 40-54.

9. L.L. Shreir, Corrosion: Corrosion Control, 2013, Newnes.

10. F.J. Ruiz-Cabañas, C. Prieto, R. Osuna, V. Madina, A.I. Fernández and L.F. Cabeza, Sol. Energy Mater. Sol. Cells, 2016, 157, 383-392.

11. C. Verma, H. Lgaz, D. Verma, E.E. Ebenso, I. Bahadur and M. Quraishi, J. Mol. Liq., 2018, 266, 577-590.

12. M. Bethencourt, F. Botana, J. Calvino, M. Marcos and M. Rodriguez-Chacon, Corros. Sci., 1998, 40, 1803-1819.

13. P.B. Raja, M.G. Sethuraman, Mater. Lett., 2008, 62, 113-116.

14. G. Gece, Corros. Sci., 2008, 50, 2981-2992.

15. K. Bouyad, Y.K. Rodi, H. Elmsellem, E. El Ghadraoui, Y. Ouzidan, I. Abdel-Rahman, H. Kusuma, I. Warad, J. Mague and E. Essassi, Moroccan J. Chem., 2018, 6, no. 1, 2022-2034.

16. T. Laabaissi, F. Benhiba, Z. Rouifi, M. Missioui, K. Ourrak, H. Oudda, Y. Ramli, I. Warad, M. Allali and A. Zarrouk, Int. J. Corros. Scale Inhib., 2019, 2, 241-256.

17. A. Khramov, N. Voevodin, V. Balbyshev, M. Donley, Thin Solid Films, 2004, 447, $549-557$.

18. S.O. Adejo, S.G. Yiase, L. Leke, M. Onuche, M.V. Atondo and T.T. Uzah, Int. J. Corros. Scale Inhib., 2019, 1, 50-61.

19. A. Zouitini, Y.K. Rodi, H.E. Chahdi, H. Steli, C. Ad, Y. Ouzidan, E. Essassi, A. Chetouani and B. Hammouti, Moroccan J. Chem., 2018, 6, no. 3, 2391-2403.

20. M. Filali, E.M. El Hadrami, A. Ben-tama， B. Hafez, I. Abdel-Rahman, A. Harrach, H. Elmsellem, B. Hammouti, M. Mokhtari, SE. Stiriba and M. Julve, Int. J. Corros. Scale Inhib., 2019, 1, 93-109.

21. C. Verma, L.O. Olasunkanmi, E.E. Ebenso, M.A. Quraishi and I.B. Obot, J. Phys. Chem. C, 2016, 120, 11598-11611.

22. I. Obot, N. Obi-Egbedi and A. Eseola, Ind. Eng. Chem. Res., 2011, 50, 2098-2110.

23. D.K. Yadav, M. Quraishi, Ind. Eng. Chem. Res., 2012, 51, 8194-8210. 
24. A. Ostovari, S. Hoseinieh, M. Peikari, S. Shadizadeh and S. Hashemi, Corros. Sci., 2009, 51, 1935-1949.

25. M. El-Naggar, Corros. Sci., 2007, 49, 2226-2236.

26. C.B. Verma, M. Quraishi and A. Singh, J. Taiwan Inst. Chem. Eng., 2015, 49, 229239.

27. L. Ljungberg, D. Cubicciotti and M. Trolle, Corrosion, 1988, 44, 66-72.

28. P. Kritzer, J. Supercrit. Fluids, 2004, 29, 1-29.

29. Y.S. Choi and S. Nešić, CORROSION/2011, NACE International, Houston, 2011, Paper No. 11377.

30. A. Rahmel, Mater. Sci. Eng., 1987, 87, 345-352.

31. M. Montemor, A. Simoes and M. Ferreira, Prog. Org. Coat., 2002, 44, 111-120.

32. P.A. Schweitzer, Corrosion of Linings and Coatings: Cathodic and Inhibitor Protection and Corrosion Monitoring, Boca Raton, FL, CRC Press, 2006.

33. W. Bjorndahl and K. Nobe, Corros., 1984, 40, 82-87.

34. M.G. Fontana, Corrosion Engineering, 2005, Tata McGraw-Hill Education.

35. H.A. Videla and W.G. Characklis, Int. Biodeterior. Biodegrad., 1992, 29, 195-212.

36. R.W. Revie, Corrosion and corrosion control, John Wiley \& Sons, 2008.

37. M. Kermani and A. Morshed, Corros., 2003, 59, 659-683.

38. C. Chen, M. Lu, D. Sun, Z. Zhang and W. Chang, Corrosion, 2005, 61, 594-601.

39. A. Popova, E. Sokolova, S. Raicheva and M. Christov, Corros. Sci., 2003, 45, 33-58.

40. A.A. Khadom, A.S. Yaro, A.A.H. Kadum, A.S. AlTaie and A.Y. Musa, Am. J. Appl. Sci., 2009, 6, 1403-1409.

41. C. Blawert, W. Dietzel, E. Ghali and G. Song, Adv. Eng. Mater., 2006, 8, 511-533.

42. C. Verma, L. Olasunkanmi, E.E. Ebenso and M. Quraishi, J. Mol. Liq., 2018, 251, $100-118$.

43. J. Leffler and E. Grunwald, Rates and Equilibria of Chemical Reactions, 1963, Wiley, New York.

44. V.S. Sastri, Green Corrosion Inhibitors: Theory and Practice, 2012, John Wiley \& Sons.

45. S.W. Pelletier, Alkaloids: Chemical and Biological Perspectives, 1999, Springer.

46. Q. Shi, S. Hui, A.-H. Zhang, X. Hong-Ying, Y. Guang-Li, H. Ying and W. Xi-Jun, Chin. J. Nat. Med., 2014, 12, 401-406.

47. M.H. Mirjalili, E. Moyano, M. Bonfill, R.M. Cusido and J. Palazón, Molecules, 2009, 14, 2373-2393.

48. T. Hartmann, Phytochemistry, 2007, 68, 2831-2846.

49. T. Hartmann, Diversity and variability of plant secondary metabolism: a mechanistic view, Proceedings of the 9th International Symposium on Insect-Plant Relationships, Springer, 1996, pp. 177-188.

50. V. Lattanzio, V.M. Lattanzio and A. Cardinali, Phytochemistry: Advances in Research, 2006, pp. 23-67. 
51. Y. Koshiro, X.-Q. Zheng, M.-L. Wang, C. Nagai and H. Ashihara, Plant Sci., 2006, 171, 242-250.

52. M.F. Roberts, Alkaloids: Biochemistry, Ecology, and Medicinal Applications, 2013, Springer Science \& Business Media.

53. M. Hesse, Alkaloids: Nature's Curse or Blessing?, 2002, John Wiley \& Sons.

54. T. Schmeller and M. Wink, Utilization of alkaloids in modern medicine, in Alkaloids, 1998, Springer, pp. 435-459.

55. S. Bent and R. Ko, Am. J. Med., 2004, 116, 478-485.

56. H.-J. Knölker and K.R. Reddy, Chem. Rev., 2002, 102, 4303-4428.

57. J. Rios, M. Recio and A. Villar, J. Ethnopharmacol., 1988, 23, 127-149.

58. E. Stupnišek-Lisac, S. Podbršček and T. Sorić, J. Appl. Electrochem., 1994, 24, 779-784.

59. E. Stupnišek-Lisac, A. Gazivoda and M. Madžarac, Electrochim. Acta, 2002, 47, $4189-4194$.

60. C. Verma, J. Haque, M. Quraishi and E.E. Ebenso, J. Mol. Liq., 2018, 275, 18-40.

61. A. Batah, A. Anejjar, M. Belkhaouda, L. Bammou, R. Salghi, L. Bazzi and B. Hammouti, Moroccan J. Chem., 2017, 5, no. 3, 2404-2416.

62. A. Satapathy, G. Gunasekaran, S. Sahoo, K. Amit and P. Rodrigues, Corros. Sci., 2009, 51, 2848-2856.

63. J. Buchweishaija, Tanzania J. Sci., 2009, 35, 77-92.

64. D. Kesavan, M. Gopiraman and N. Sulochana, Chem. Sci. Rev. Lett., 2012, 1, 1-8.

65. H.I. El-Subbagh, S.M. Abu-Zaid, M.A. Mahran, F.A. Badria and A.M. Al-Obaid, J. Med. Chem., 2000, 43, 2915-2921.

66. J.A. Bull, J.J. Mousseau, G. Pelletier and A.B. Charette, Chem. Rev., 2012, 112, 2642-2713.

67. A.A. Altaf, A. Shahzad, Z. Gul, N. Rasool, A. Badshah, B. Lal and E. Khan, J. Drug Design Med. C., 2015, 1, 1-11.

68. J.-P. Kaplan, P. George, 1983, Imidazo(1,2,-a)pyridine derivatives and pharmaceutical compositions, Google Patents (Patent Number: NZ203956A), 1983.

69. K. Ansari, M. Quraishi and A. Singh, Measurement, 2015, 76, 136-147.

70. A. Kosari, M.H. Moayed, A. Davoodi, R. Parvizi, M. Momeni, H. Eshghi and H. Moradi, Corros. Sci., 2014, 78, 138-150.

71. M. Goyal, S. Kumar, I. Bahadur, C. Verma and E.E. Ebenso, J. Mol. Liq., 2018, 256, 565-573.

72. S.A. El-Maksoud and A. Fouda, Mater. Chem. Phys., 2005, 93, 84-90.

73. A. Espinoza, S. García and F. Rodríguez, J. Anal. Bioanal. Tech., 2015, 6, 2-7.

74. A. Espinoza-Vázquez and F. Rodríguez-Gómez, RSC Adv., 2016, 6, 70226-70236.

75. M. Vinutha, T. Venkatesha and V. Bhat, Port. Electrochim. Acta, 2017, 35, 253-268.

76. R. Kanojia and G. Singh, Surf. Eng., 2005, 21, 180-186.

77. H. Ju and Y. Li, Corros. Sci., 2007, 49, 4185-4201. 
78. D.K. Singh, S. Kumar, G. Udayabhanu and R.P. John, J. Mol. Liq., 2016, 216, $738-746$.

79. G. Kavithaa and C. Vedhi, Int. J. Appl. Chem., 2017, 13, 567-584.

80. M.D. Padma and T. Rama Char, Anti-Corros. Methods Mater., 1969, 16, $22-24$.

81. D. Pisanenko, Y.E. Klimko and A. Gaidai, 2016, 2, 45-49.

82. M. Chigondo and F. Chigondo, J. Chem., 2016, 1-7.

83. C. Loto and R. Loto, Int. J. Electrochem. Sci., 2011, 6, 3830-3843.

84. H. Wang, M. Gao, Y. Guo, Y. Yang and R. Hu, Desalination, 2016, 398, 198-207.

85. J. Bhawsar, P. Jain and P. Jain, Alexandria Eng. J., 2015, 54, 769-775.

86. A. Zacharopoulou, G. Batis, V. Argyropoulou and E. Guilminot, Int. J. Conserv. Sci., 2016, 7, 259-264.

87. J. Zhao, N. Zhang, C. Qu, J. Zhang and X. Zhang, Ind. Eng. Chem. Res., 2010, 49, $12452-12460$.

88. S. Agarwal, S. Cammerer, S. Filali, W. Frohner, J. Knoll, M.P. Krahl, K.R. Reddy and H.-J. Knolker, Curr. Org. Chem., 2005, 9, 1601-1614.

89. S.-M. Li, Nat. Prod. Rep., 2010, 27, 57-78.

90. J. Sugden and T. Yoloye, Pharm. Acta Helv., 1978, 53, 65-92.

91. C. Verma, M.A. Quraishi, E.E. Ebenso, I.B. Obot and A. El Assyry, J. Mol. Liq., 2016, 219, 647-660.

92. M. Lebrini, F. Robert, H. Vezin and C. Roos, Corros. Sci., 2010, 52, 3367-3376.

93. K. Khaled, Mater. Chem. Phys., 2008, 112, 290-300.

94. C. Verma, M. Quraishi, E. Ebenso and I. Obot, J. Mol. Liq., 2016, 219, 647-660.

95. C. Kamal and M.G. Sethuraman, Ind. Eng. Chem. Res., 2012, 51, 10399-10407.

96. P.B. Raja, M. Fadaeinasab, A.K. Qureshi, A.A. Rahim, H. Osman, M. Litaudon and K. Awang, Ind. Eng. Chem. Res., 2013, 52, 10582-10593.

97. I. Obot and N. Obi-Egbedi, Port. Electrochim. Acta, 2009, 27, 517-524.

98. M. Lebrini, F. Robert and C. Roos, Int. J. Electrochem. Sci., 2010, 5, 1698-1712.

99. P.B. Raja, A.K. Qureshi, A.A. Rahim, H. Osman and K. Awang, Corros, Sci., 2013, 69, 292-301.

100. P.B. Raja, A.K. Qureshi, A.A. Rahim, K. Awang, M.R. Mukhtar and H. Osman, J. Mater. Eng. Perform., 2013, 22, 1072-1078.

101. M. Faustin, A. Maciuk, P. Salvin, C. Roos and M. Lebrini, Corros. Sci., 2015, 92, 287-300.

102. A. Djemoui, L. Souli, D. Djemoui and M. Okazi, J. Chem. Pharm. Res., 2017, 9, no. 3, 311-318.

103. N. Chaubey, D.K. Yadav, V.K. Singh and M. Quraishi, Ain Shams Eng. J., 2017, 8, 673-682.

104. M. Legraverend and D.S. Grierson, Bioorg. Med. Chem., 2006, 14, 3987-4006.

105. D. Woolley, J. Biol. Chem., 1944, 152, 225-232.

106. N.O. Eddy, H. Momoh-Yahaya and E.E. Oguzie, J. Adv. Res., 2015, 6, 203-217. 
107. Y. Yan, W. Li, L. Cai and B. Hou, Electrochim. Acta, 2008, 53, 5953-5960.

108. M. Scendo, Corros. Sci., 2007, 49, 2985-3000.

109. F.S. de Souza, C. Giacomelli, R.S. Gonçalves and A. Spinelli, Mater. Sci. Eng.: C, 2012, 32, 2436-2444.

110. S. Gudić, E.E. Oguzie, A. Radonić, L. Vrsalović, I. Smoljko and M. Kliškić, Maced. J. Chem. Chem. Eng., 2014, 33, 13-25.

111. T. Fallavena, M. Antonow and R.S. Gonçalves, Appl. Surf. Sci., 2006, 253, 566-571.

112. V. Kouakou, P.M. Niamien, A.J. Yapo, S. Diaby and A. Trokourey, Orbital: Electron. J. Chem., 2016, 8, 66-79.

113. M. Romas, A. Munoz, D. Mareci, C. Vidal, S. Curteanu and D. Sutiman, Chem. Pap., 2014, 68, 1066-1078.

114. M. Ebadi, W. Basirun, S. Leng and M. Mahmoudian, Int. J. Electrochem. Sci., 2012, 7, 8052-8063.

115. S. Rajendran, A.J. Amalraj, M.J. Joice, N. Anthony, D. Trivedi and M. Sundaravadivelu, Corros. Rev., 2004, 22, 233-248.

116. E.C.d.C.A. Souza, B.d.A. Ripper, D. Perrone and E. D'Elia, Mater. Res., 2016, 19, $1276-1285$.

117. L.G. da Trindade and R.S. Goncalves, Corros. Sci., 2009, 51, 1578-1583.

118. R. Beda, P. Niamien, E. Avo Bilé and A. Trokourey, Adv. Chem., 2017, 1-10.

119. A. Samide, B. Tutunaru, C. Ionescu, P. Rotaru and L. Simoiu, J. Therm. Anal. Calorim., 2014, 118, 631-639. 